\title{
ANALYSIS OF THE VITAMIN D RECEPTOR BSMI GENE POLYMORPHISM IN CHILDREN WITH GROWTH HORMONE DEFICIENCY
}

DOI: 10.36740/WLek202103121

\author{
Elena V. Bolshova' ${ }^{1}$ Mariana A. Ryznychuk' ${ }^{2}$ Dmitry A. Kvacheniuk' \\ IINSTITUTION «V.P. KOMISARENKO INSTITUTE OF ENDOCRINOLOGY AND METABOLISM OF THE NATIONAL ACADEMY OF MEDICAL SCIENCES \\ OF UKRAINE», KYIV, UKRAINE \\ 2HIGHER STATE EDUCATIONAL ESTABLISHMENT OF UKRAINE"BUKOVINIAN STATE MEDICAL UNIVERSITY", CHERNIVTSI, UKRAINE
}

\begin{abstract}
The aim: The objective of the study was to investigate the polymorphism of the vitamin D receptor (VDR) Bsml gene in children with growth hormone deficiency and the level of their vitamin D supply.

Materials and methods: Sixteen children diagnosed with of growth hormone deficiency who were treated at the State Institution «V.P. Komisarenko Institute of Endocrinology and Metabolism of the National Academy of Medical Sciences of Ukraine» were examined. The patient's gender and age, the anthropometric data, the vitamin D level in the blood, the bone age, the GH level, the IGF-1 levels, the level of calcium in the blood and VDR gene polymorphism were taken into account.

Results: It was shown that in the presence of the $G / A$ genotype, the risk of growth hormone deficiency development was increased $0 R=1,096(95 \% \mathrm{Cl} 0.39-3.02 ; p=0.86)$. For Bsml, mean values of height, body mass, height SDS, serum $25(\mathrm{OH}) \mathrm{D}$, in the studied population (16 children) were $123.49 \pm 19.62 \mathrm{~cm}, 26.96 \pm 11.11 \mathrm{~kg},-2.25 \pm 0.85,48.86 \pm$ $16.71 \mathrm{nmol} / \mathrm{l}$, respectively; total calcium level consisted of $2.40 \pm 0.12 \mathrm{mmol} / \mathrm{l}$, serum phosphorus $-1.43 \pm 0.11 \mathrm{mmol} / \mathrm{l}$.

Conclusions: The allele frequency of the VDR Bsml polymorphism was $62.5 \%$ for the $G$ allele $(n=20)$ and $37.5 \%$ for the allele $A(n=12)$. The $G$ allele carrier of the polymorphic locus Bsml rs 1544410 of the VDR gene (rs11568820) is associated with an increased risk of growth hormone deficiency development $0 R=1.31(95 \%(\mathrm{Cl} 0.62-2.75 ; \mathrm{p}=0.47)$.
\end{abstract}

KEY WORDS: VDR gene, children, growth hormone deficiency, polymorphism

Wiad Lek. 2021;74(3 p.l):498-503

\section{INTRODUCTION}

As is generally known the vitamin $\mathrm{D}$ and its active metabolites play a key role in phosphorus-calcium homeostasis and bone metabolism, regulate the cell growth and differentiation in different target organs [1,2].

The vitamin $\mathrm{D}$ is a ligand for the nuclear receptor which is encoded by the VDR gene and is a regulator of the activity of many target genes by interacting with specific DNA sequences in the promoter regions of these genes [3].

The vitamin $\mathrm{D}$ levels are generally lower in patients with growth hormone $(\mathrm{GH})$ deficiency than in the control group with different prevalence of insufficiency or deficiency, and this status may make worse the already known cardiovascular and metabolic risks of growth hormone deficiency, although this statement (affirmation) is not generalized for all the studies. In addition, data on the effect of growth hormone treatment on vitamin $\mathrm{D}$ levels in patients with $\mathrm{GH}$ deficiency are quite controversial. On the contrary, in active acromegaly, a condition characterized by chronic growth hormone excess, both increased and decreased levels of vitamin $\mathrm{D}$ have been observed, and the interaction between vitamin D and the growth hormone / IGF-1 axis becomes even more complex when considering acromegaly treatment [4].
Hamza R.T. et al. (2018) evaluated the vitamin D status in prepubertal children with idiopathic growth hormone deficiency and the effect of treatment on the vitamin D level. The vitamin D deficiency was revealed in $40 \%$ of children with idiopathic growth hormone deficiency; a deficiency was found in $44 \%$, a sufficient level of the vitamin D was only observed in $16 \%$. A positive correlation between the vitamin $\mathrm{D}$ and peak GH levels was noted. The GH peak was a significant predictor of the vitamin D levels. After 1 year growth hormone therapy, the level of vitamin D was significantly increased. Overall, the level of vitamin D remained insufficient in $22 \%$ of cases and the vitamin $\mathrm{D}$ deficiency was found in $24 \%$ of children. It was proved that Vitamin D negatively correlated with parathyroid hormone (PTH). Therefore, hypovitaminosis D is common in children with idiopathic growth hormone deficiency and was significantly reduced 1 year after GH therapy [5].

P. Ameri, et al. [6] and F. Bogazzi, et al. [7] show that the vitamin D levels affect the function of the GH / IGF-1 axis. Vitamin $\mathrm{D}$ can increase the production and secretion of IGF-1 (insulin-like growth factor-1) and IGFBR-3 (insulin like growth factor binding protein 3 ) in the liver. On the other hand, both STH and IGF-1 increase renal production of vitamin $\mathrm{D}$ by increasing the kidney activity 
of 1a-hydroxylase [8]. During the vitamin D therapy the effect of recombinant $\mathrm{GH}(\mathrm{rGH})$ on the bone formation in GH treatment [9].

The main function of the vitamin D substances is, first of all, to regulate the bone metabolism. Only $10-15 \%$ of calcium and about $60 \%$ of phosphorus are absorbed without the vitamin D participation. 1.25(OH)2D - a hormone-active form of vitamin $\mathrm{D}$, interacting with the VDR, increases the absorption of intestinal calcium and phosphorus by $30-40$ $\%$ and $80 \%$, respectively. At the same time, the process of calcium mobilization from the bone tissue is controlling by vitamin $\mathrm{D}$, which is also necessary to create optimal conditions for its growth. Calcium and phosphate metabolism are regulated not only by vitamin D but also by the level of ionized calcium, PTH and calcitonin [10].

The vitamin D receptor belongs to a family of transactive transcription regulatory factors and has a similarity to the steroid and thyroid hormone receptors, confirming the functioning of vitamin $\mathrm{D}$ as a hormone $[11,12]$.

Vitamin $\mathrm{D}$ receptors are known to be encoded by the eponymous VDR gene (also known as NR1I1) localized on chromosome 12q12-q14.

This gene is characterized by polymorphism, that is, the existence of its different allelic variants in the population. The most significant are polymorphisms of the VDR gene involved in disease development: BsmI, FokI, TaqI Fokl, ApaI [12]. To date, 1518 single-nucleotide polymorphisms (SNPs) of the human VDR gene have been described.

Among them is BsmI, localized in the eighth intron. The nature of the BsmI polymorphism lies in the fact that guanine is substituted for adenine at position 58980. By themselves, polymorphisms in introns are not functionally significant, since they do not change the sequence of the nitrogenous bases in the content part of the gene, however, being linked to the regulatory regions of the gene, may serve as markers of functional relationships of other polymorphisms with the development of pathological processes and diseases. The association of BsmI polymorphism with different pathological processes and diseases has been studied in many trials of different populations. In some of them, this SNP was associated with osteoporosis [13], pathological fractures [14], type 2 diabetes [15], prostate cancer [16], breast cancer [17], Parkinson's disease [18].

\section{THE AIM}

The aim was to investigate the polymorphism of the VDR BsmI gene in children with growth hormone deficiency and the level of their vitamin D supply.

\section{MATERIALS AND METHODS}

The serum 25-hydroxycalciferol (25(OH)D) level was determined by immunochemiluminescent method. The GH and IGF-1 levels were studied using radioimmunoassay and enzyme immunoassay methods. The control group consisted of 250 healthy children and adolescents aged 9 to 18 (mean age $8.24 \pm 3.83$ years) [19]. Sixteen children were examined with diagnosis of GH deficiency who were treated at the State Institution «V.P. Komisarenko Institute of Endocrinology and Metabolism of NAMS of Ukraine». The patient's sex and age, anthropometric data, vitamin $\mathrm{D}$ level in the blood (excluded summer months of patient recruitment), bone age, GH level after stimulation tests (clonidine, insulin), IGF-1 levels, blood levels of total and ionized calcium were taken into account. The mean age of children (11 boys, 5 girls) who were included in the study was $10 \pm 3.0$ years. The average growth delay was minus $2.25( \pm 0.85)$ SDS. At the time of the examination, all the patients were in a euthyroid state. The study included children who had not received the calcium and vitamin D drugs for 6 months. Children with growth hormone deficiency had a significant decrease in IGF-1 levels (from 27.83 to $94.89 \mathrm{ng} / \mathrm{ml}$ ). Statistical processing of the study results was performed using Microsoft Excel statistical programs.

In order to verify the diagnosis of vitamin D insufficiency and deficiency, the classification (2011) was adopted by the International Institute of Medicine and Endocrine Medicine, Committee practical guidelines. According to this classification, the vitamin D deficiency in children and adults is considered to be a clinical syndrome due to low serum $25(\mathrm{OH}) \mathrm{D}$ level (below $20 \mathrm{ng} / \mathrm{ml}$ or $50 \mathrm{nmol} / \mathrm{l}$ ). The serum 25(OH)D level from $21 \mathrm{ng} / \mathrm{ml}$ to $29 \mathrm{ng} / \mathrm{ml}$ (from 50.1 to $74.9 \mathrm{nmol} / \mathrm{l}$ ) should be considered as the vitamin $\mathrm{D}$ deficiency. The normal level of vitamin $\mathrm{D}$ is equal to the serum 25(OH)D concentration above $30 \mathrm{ng} / \mathrm{ml}$.

The determination of VDR BsmI gene (rs1544410) polymorphism was performed using the polymerase chain reaction (PCR) method, followed by analysis of the length of the restriction fragments upon their detection by agarose gel electrophoresis.

For genotyping, the venous blood was collected under sterile conditions in $2.7 \mathrm{ml}$ monovets with potassium salt of ethylenediaminetetraacetic acid ("Sarstedt", Germany), which served as an anticoagulant. First, DNA was eliminated from the peripheral blood using a commercial Quick-DNA ${ }^{\mathrm{TM}}$ Miniprep Plus Kit (manufactured by Zymo Research, USA).

The genes studied were amplified using specific primers ( Metabion, Germany) and commercial Dream Taq Green PCR Master Mix ( Thermo Scientific, USA). The tubes with the final amplification mixture were transferred to the Flex Cycler BU amplifier (Analytic Jena, Germany) to provide the appropriate temperature regime.

The amplification products of DNA fragments (amplicons) of the VDR gene were subjected to hydrolytic cleavage by restriction endonuclease BsmI ( Thermo Scientific, USA), respectively. Separate mixtures were prepared for restriction analysis and transferred to pre-labeled tubes, and then the amplicons were added.

The fragment limiting reaction for the BsmI G / A (rs1544410) of the VDR gene was performed according to the manufacturer's recommendations in a solid-state micro thermostat at $37^{\circ} \mathrm{C}$ for 16 hours.

The process was stopped by increasing the temperature to $65^{\circ} \mathrm{C}$ for 20 minutes. The state of the restriction fragments 
of the VDR gene was analyzed by a 3\% agarose gel (agarose firm Cleaver Scientific, UK), with the addition of ethidium bromide, a marker of molecular weight "GeneRuler $50 \mathrm{bp}$ DNA Ladder" (Thermo Scientific, USA) and subsequent visualization using a transilluminator stained with ethidium bromide by computer program "Vitran".

Amplifiers of the VDR BsmI G / A gene (rs1544410) were hydrolytically cleaved in the presence of a 5'-GAATGCN $\downarrow-3$ 'restriction site, resulting in the restriction formations with molecular mass a $644 \mathrm{bp}$ and $179 \mathrm{bp}$ - the GG genotype. The restriction site disappeared with nucleotide replacement from $\mathrm{G}$ to $\mathrm{A}$, if the size of the amplified DNA fragments remained unchanged after interaction with the restriction nuclease $(823 \mathrm{bp})$, then the AA genotype was recorded. Accordingly, all three types of fragments: 823, 644 and $179 \mathrm{pp}$ in the heterozygous genotype (GA) were simultaneously observed.

The data obtained were statistically analyzed using Statistica 6.1 and SPSS17.0 software package (SPSS, Inc., Chicago, IL, USA). General statistical analysis included median (Me) and interquartile interval' (UQ-LQ) calculations. Laboratory parameters were presented in the form of arithmetic data (mean $(\mathrm{M} \pm \mathrm{m})$, standard error of mean) (SEM). For nominal variables, the ratios were calculated using the Pearson test ( $\left.\chi^{2}\right)$ and the Fisher test (two-sided); these differences were considered statistically significant for which the $\mathrm{P}$ value was $<0.05$.

The study was conducted in accordance with the basic principles of bioethics of the Council of Europe Convention on Human Rights and Biomedicine (the $4^{\text {th }}$ of April 1997), the World Health Association Helsinki Declaration on Ethical Principles for Conducting Medical Research with the Participation of People (1964-2013). Commission on Biomedical Ethics of the State Institution «V.P. Komisarenko Institute of Endocrinology and Metabolism of the National Academy of Medical Sciences of Ukraine" did not find violations of moral norms during the study. Informed consent was obtained from the participants and their parents.

\section{RESULTS}

Acting through its receptor, the hormone-active form of vitamin $\mathrm{D}-1.25(\mathrm{OH})_{2} \mathrm{D}$ can cause many effects that affect various biological processes in the body.

In the target tissues, the vitamin $\mathrm{D}$ receptors are functioning in both the cell nuclei (gene regulation level) and plasma membranes (non-gene regulation level). At the gene level, active metabolites of vitamin $\mathrm{D}$ bind to specific receptors, forming the hormone receptor complex D3-VDR, which has its own specific DNA-binding domain (a specific DNA sequence), thereby controlling the transcription of the corresponding genes. This process, in one's turn, leads to the biosynthesis of new mRNA molecules and the translation of the corresponding proteins involved in the physiological responses) [11,12].

Analysis of the distribution of allele and genotype frequencies of the polymorphic locus BsmI (rs1544410) gene in the group of patients with GH deficiency and in the control sample [19] is statistically significant (Table 1).

The allele frequency of the VDR BsmI polymorphism was $62.5 \%$ for the $G$ allele $(n=20)$ and $37.5 \%$ for the allele A $(\mathrm{n}=12)$. The study found that the $G$ allele carriers of polymorphic locus BsmI (rs1544410) of the vitamin D receptor gene ( $r s 11568820$ ) is associated with an increased risk of growth hormone deficiency OR $=1,31(95 \% \mathrm{CI}$ $0.62-2.75 ; \mathrm{p}=0.47$ ).

It was also shown that the risk of growth hormone deficiency is increased in the presence of the G/A genotype, $\mathrm{OR}=1.096$ (95\% CI 0.39-3.02; $\mathrm{p}=0.86$ ); also in $\mathrm{G} / \mathrm{G}$ variant, the risk of growth hormone deficiency was $\mathrm{OR}=1.27$ (95\% CI 0.44-3.63; $\mathrm{p}=0.65)$; in the A/A genotype variant, the risk of growth hormone deficiency was minimal $\mathrm{OR}=0.56$ (95\% CI 0.12-2.58; $\mathrm{p}=0.46)$.

For BsmI, mean values of height, weight, height SDS, serum $25(\mathrm{OH}) \mathrm{D}$, in the studied population (16 children) were $123.49 \pm 19.62 \mathrm{~cm}, 26.96 \pm 11.11 \mathrm{~kg},-2.25 \pm 0.85$, $48,86 \pm 16,71 \mathrm{nmol} / \mathrm{l}$, respectively, level of total calcium $-2,40 \pm 0,12 \mathrm{mmol} / \mathrm{l}$, serum phosphorus $-1,43 \pm 0,11$ $\mathrm{mmol} / \mathrm{l}$ (Table 2).

The vitamin $\mathrm{D}$ deficiency is occurred in all the children with growth hormone deficiency regardless of the polymorphic locus rs1544410 BsmI of the vitamin D receptor gene. Vitamin $\mathrm{D}$ was significantly lower $(32.05 \pm 11.67$ $\mathrm{nmol} / \mathrm{l}$ ) in children with polymorphic variant $\mathrm{G} / \mathrm{C}$ than that in children with other VDR BsmI polymorphisms, but not significantly.

The GH level after the clonidine stimulation test was significantly lower in group with the VDR BsmI polymorphic variant A / A (0.65 $\pm 0.05 \mathrm{ng} / \mathrm{ml})$, and significantly higher in the VDR BsmI polymopphic G/G variant $(5.59 \pm 0.42 \mathrm{ng} / \mathrm{ml})$.

Growth SDS (Standard Deviation Score) was significantly lower in the group of children with polymorphic variant A / A (-3.09 \pm 0.12$)$ compared to variants of the polymorphic locus BsmI (rs1544410) of the VDR gene G/A $(-2.02 \pm 0,42)$ and G / G (-2.51 \pm 1.35$)$.

IGF-1 in all surveyed was low with polymorphic variant G / G VDR BsmI (94.89 $\pm 44.34 \mathrm{ng} / \mathrm{ml})$, with polymorphic variants G / A and A / A as well, but not significantly $(27.83 \pm 12.61 \mathrm{ng} / \mathrm{ml}$ and $37.75 \pm 18.03 \mathrm{ng} / \mathrm{ml}$, respectively). Normal levels of total and ionized calcium in serum were found in all the children examined.

\section{DISCUSSION}

The vitamin D and IGF-1 levels affect each other: on the one hand, the increase in vitamin $\mathrm{D}$ increases the level of IGF-1 [20], and on the other hand, IGF-1 stimulates the activity of the enzyme 1 $a$-hydroxylase, which, in one's turn, regulates the renal production of vitamin $\mathrm{D}: 1,25(\mathrm{OH})_{2} \mathrm{D}$ or calcitriol [21].

In addition, $\mathrm{GH}$ itself has a direct stimulating effect on the production of $1.25(\mathrm{OH})_{2} \mathrm{D}$ [22]. Besides, both $\mathrm{GH}$ and IGF-1 seem to increase the activity of CYP27A1, a multifunctional cytochrome P450 enzyme that catalyzes 25-hydroxylation of vitamin D in hepatoblastoma cells [23]. 
Table 1. Distribution of allele and genotype frequencies of the polymorphic locus of vitamin D receptor gene Bsml-rs 1544410 in the group of patients with growth hormone deficiency and in the control sample

\begin{tabular}{|c|c|c|c|c|c|c|c|}
\hline \multirow{2}{*}{$\begin{array}{l}\text { Groups and number } \\
\text { individuals (n) }\end{array}$} & \multicolumn{2}{|c|}{ Allele' frequencies, \% } & \multirow{2}{*}{$\begin{array}{c}x^{2} \\
d f=1\end{array}$} & \multicolumn{3}{|c|}{ Genotype frequencies, \% } & \multirow{2}{*}{$\begin{array}{l}x^{2} \\
d f=2\end{array}$} \\
\hline & G & A & & $\mathbf{G} / \mathbf{A}$ & G/G & A/A & \\
\hline Population sample $(218)^{*}$ & $244(56)$ & $192(44)$ & \multirow{2}{*}{$\begin{array}{c}0,52 \\
p=0,47\end{array}$} & $104(47,7)$ & $70(32.1)$ & $44(20.2)$ & \multirow{2}{*}{$\begin{array}{c}0.59 \\
p=0.74\end{array}$} \\
\hline Patients with GH deficiency & $20(62.5)$ & $12(37.5)$ & & $8(50)$ & $6(37.5)$ & $2(12.5)$ & \\
\hline
\end{tabular}

Note: Hardy-Weinberg equilibrium for $\mathrm{Bsml}(\mathrm{P}=0.79)$

* - data from source19.

Table 2. Effect of VDR polymorphism on growth values and some serum biochemical parameters in children with growth hormone deficiency

\begin{tabular}{cccc}
\hline & & \multicolumn{2}{c}{ Genotype } \\
Values & \multicolumn{3}{c}{ Bsml (rs1544410), $\mathbf{n = 1 6}$} \\
\cline { 2 - 4 } & GA & GG & AA \\
\hline Growth SDS & $-2.02 \pm 0.42$ & $-2.51 \pm 1.35$ & $-3.09 \pm 0.12^{*}$ \\
\hline GH level after stimulation testwith clonidine, $\mathrm{ng} / \mathrm{ml}$ & $2.12 \pm 0.12$ & $5.59 \pm 0.42^{*}$ & $0.65 \pm 0.05^{* *}$ \\
\hline $25(\mathrm{OH}) \mathrm{D}, \mathrm{nmol} / \mathrm{l}$ & $47.63 \pm 16.91$ & $32.05 \pm 11.67$ & $41.52 \pm 4.41$ \\
\hline IGF-1, $\mathrm{ng} / \mathrm{ml}$ & $27.83 \pm 12.61$ & $94.89 \pm 44.34$ & $37.75 \pm 18.03$ \\
\hline The total calcium, $\mathrm{mmol} / \mathrm{l}$ & $2.44 \pm 0.09$ & $2.43 \pm 0.11$ & $2.20 \pm 0.13$ \\
\hline Calcium ionized, $\mathrm{mmol} / \mathrm{l}$ & $1.19 \pm 0.06$ & $1.22 \pm 0.07$ & $1.11 \pm 0.01$ \\
\hline
\end{tabular}

Note: * - the significance level between values of the Bsml (rs1544410) GA and GG genotypes ( $p<0.05)$;

** - significance level between the values of Bsml (rs1544410) GA and AA genotypes $(p<0.05)$.

Another target, which is rich in VDR, is represented by the pituitary gland. It is likely that $1.25(\mathrm{OH})_{2} \mathrm{D}$ acts on the human pituitary VDR, stimulating GH secretion and modulating the expression of some genes [24].

G. Saggese et al. [25] studied the status of vitamin D in 26 children with GH deficiency and found normal concentrations of $25 \mathrm{OHD}$ but low levels of $1.25(\mathrm{OH})_{2} \mathrm{D}$ before growth hormone (treatment and a significant increase in $1.25(\mathrm{OH})_{2} \mathrm{D}$ levels after 12 months of $\mathrm{rGH}$ treatment. Data of 80 Sicilian children with growth hormone deficiency were analyzed by A. Ciresi et al. ${ }^{8}$ These authors reported of the higher $25 \mathrm{OHD}$ values in children with growth hormone deficiency in the solar seasons $(31.1 \pm 11.1 \mathrm{ng} /$ $\mathrm{ml}$ in June - September) than in the cold season (17.3 \pm $5.3 \mathrm{ng} / \mathrm{ml}$ in November - February), $35 \%$ of children have vitamin D insufficiency and 40\% - vitamin D deficiency. E. Witkowska-Sedek et al. studied 84 children and adolescents with GH deficiency and found the low concentrations of $25 \mathrm{OHD}(22.3 \pm 6.9 \mathrm{ng} / \mathrm{ml})$ [26], and M.C. Savanelli et al. analyzed 41 adult patients with growth hormone deficiency and found an average 25OHD concentration of $21.3 \pm$ $12.3 \mathrm{ng} / \mathrm{ml}$, the vitamin D deficiency was found in $51 \%$ of patients compared with $14.6 \%$ of the control group ${ }^{27}$. In addition, P. Ameri et al. found 69 adult patients with $\mathrm{GH}$ deficiency and only 6 patients $(8.7 \%)$ had a normal serum concentration of $25 \mathrm{OHD}$ more than $30 \mathrm{ng} / \mathrm{ml}$. They also reported a positive correlation between the vitamin D status and IGF-1, and found a tendency in treatment to increase doses of growth hormone in patients with the vitamin D deficiency $(25 \mathrm{OHD}<15 \mathrm{ng} / \mathrm{ml})$, suggesting that the better vitamin $\mathrm{D}$ level may facilitate the achievement of normal IGF-1 level in patients with growth hormone deficiency. In the literature review, these authors suggested that the assessment of the vitamin D levels may be an appropriate method for determining the doses of recombinant GH for the treatment of adult patients with GH deficiency [6].

Taking into account that $\mathrm{GH}$ increases $1.25(\mathrm{OH})_{2} \mathrm{D}$ level $[20,25,28-29]$, although very likely indirectly by IGF- 1 , it can be considered that patients with growth hormone deficiency due to detachment of the pituitary leg have a low concentration of serum $1.25(\mathrm{OH})_{2} \mathrm{D}$. In our study, all the children with $\mathrm{GH}$ deficiency had the $25(\mathrm{OH}) \mathrm{D}$ deficiency.

The analysis of important VDR polymorphisms in the pathogenesis of various diseases is difficult. Discovering the genetic variants associated with susceptibility to diseases may be the key to their preventing. Thus, VDR regulates the expression of a number of genes in the bone cells, many of which are encoded bone remodeling, have catabolic or anabolic actions, as well as stimulate the secretion of hormones that affect the vitamin $\mathrm{D}$ metabolism and mineral metabolism.

The role of VDR gene polymorphisms in the formation of skeletal pathology was actively studied. Thus, a study of the association of BsmI polymorphism with osteoporosis in different parts of the skeleton in postmenopausal women revealed a positive association of the disease with the genotype $G / G(p=0.009)$ and the $G$ allele $(p=0.016)$ polymorphism [30]. L. Bao et al. in a meta-analysis showed that genetic BsmI polymorphism correlates with the level of bone mineral density in children, in particular the $b(G)$ allele and the $b / b(G / G)$ genotype are more likely to occur in children with the higher bone mineral density [3].

\section{CONCLUSIONS}

1. The allele frequency of the VDR BsmI polymorphism was $62.5 \%$ for the $G$ allele $(n=20)$ and $37.5 \%$ for the $A$ allele $(n=12)$. $G$ allele carriers of the BsmI ( $r s 1544410)$ polymorphic locus of the VDR gene (rs11568820) was 
associated with an increased risk of growth hormone deficiency OR $=1.31$ (95\% CI 0.62-2.75; $\mathrm{p}=0.47)$.

2. It was also shown that in the presence of the G / G genotype, the risk of growth hormone deficiency was $\mathrm{OR}=1.27$ (95\% CI 0.44-3.63; $\mathrm{p}=0.65)$.

3. The vitamin $\mathrm{D}$ deficiency occurred in all children with growth hormone deficiency regardless of the BsmI rs1544410 polymorphic locus of the vitamin D receptor gene. In children with the BsmI polymorphic variant of G/ G VDR the level of vitamin D was significantly lower $(32.05 \pm 11.67 \mathrm{nmol} / \mathrm{l})$ than in children with other VDR BsmI polymorphisms, but not significantly.

\section{REFERENCES}

1. Baldock P.A., Thomas G.P., Hodge J.M. et al. Vitamin D action and regulation of bone remodeling: suppression of osteoclastogenesis by the mature osteoblast . J Bone Min Res. 2006; 21(10): 1618-1626 . doi: $10.1359 / \mathrm{jbmr} .060714$.

1. Pike J.W.,Zella L.A., Meyer M.B. etal. Molecular actions of 1,25-Dihydroxy vitamin D 3 on genes involved in calcium homeostasis. J Bone Min Res. 2007; 22(1): 16-19. doi: 10.1016/0026-0495(75)90055-4 .

2. Bao L., Chen M., Lei Y. et al. Association between vitamin D receptor Bsml polymorphism and bone mineral density in pediatric patients: A meta-analysis and sys tematic review of observational studies. Medicine (Baltimore).2017;96(17): e6718. doi: 10.1097/MD.0000000000006718.

3. Ciresi A., Giordano C. Vitamin D across growth hormone (GH) disorders: From GH deficiency to GH excess. Growth Hormone \& IGF Research. 2017; 33: 35-42. doi: 10.1016/j.ghir.2017.02.002.

4. Hamza R.T., Hamed A.I., Sallam M.T. Vitamin D status in prepubertal children with isolated idiopathic growth hormone deficiency: effect of growth hormone therapy Journal of Investigative Medicine. 2018; 66(5): 1-8. doi: 10.1136/jim-2017-000618.

5. Ameri P., Giusti A., Boschetti M. et al. Vitamin D increases circulating IGF1 in adults: potential implication for the treatment of $\mathrm{GH}$ deficiency. European Journal of Endocrinology. 2013; 169(6):767-72. doi: 10.1530/EJE-13-0510.

6. Bogazzi F., Rossi G., Lombardi M. et al. Vitamin D status may contribute to serum insulin-like growth factor I concentrations in healthy subjects. Journal of Endocrinological Investigation. 2011; 34(8): e200-3. doi: $10.3275 / 7228$

7. Ciresi A., Cicciò F., Giordano C. High prevalence of hypovitaminosis $D$ in Sicilian children affected by growth hormone deficiency and its improvement after 12 months of replacement treatment. Journal of Endocrinological Investigation. 2014; 37(7): 631-8. doi: 10.1007/ s40618-014-0084-7.

8. Witkowska-Sędek E., Stelmaszczyk-Emmel A., Majcher A. et al. The relationship between alkaline phosphatase and bone alkaline phosphatase activity and the growth hormone/insulin-like growth factor- 1 axis and vitamin D status in children with growth hormone deficiency. Acta Biochimica Polonica. 2018; 65(2): 269-275. doi: 10.18388/abp.2017_2541.

9. Shih E.V., Milotova N.M. Rol polimorfizma gena VDR, kodiruyuschego retseptor vitamina $D$, v patogeneze arterialnoy gipertonii [Role of the VDR gene encoding the vitamin $D$ receptor in the pathogenesis of hypertension]. Biomedttsina. 2009; 1:55-67 (in Russian).

10. Holick M.F., Binkley N.C., Bischoff-Ferrari H.A. et al. Evaluation, treatment, and prevention of vitamin $D$ deficiency: an Endocrine Society clinical practice guideline. J Clin Endocrinol Metab. 2011;96(7): 1911-30. doi: 10.1210/jc.2011-0385.
11. Uitterlinden A.G., Fang Y., Van Meurs J.B. et al. Genetics and biology of vitamin D receptor polymorphisms: Review. Gene. 2004; 338: 143-156. doi: 10.1016/j.gene.2004.05.014.

12. Tanriover M.D., Tatar G.B., Uluturk T.D. et al. Evaluation of the effects of vitamin $D$ receptor and estrogen receptor 1 gene polymorphisms on bone mineral density in postmenopausal women. Clin Rheumatol. 2010; 29(11): 1285-93. doi: 10.1007/s10067-010-1548-6.

13. Chatzipapas C., Boikos S., Drosos G.I. et al. Polymorphisms of the Vitamin D Receptor Gene and Stress Fractures. Horm Metab Res. 2009; 41(8): 635-40. doi: 10.1055/s-0029-1216375.

14. Ortlepp J.R., Lauscher J., Hoffmann R. et al. The VDR gene variant is associated with the prevalence of Type 2 diabetes mellitus and coronary artery disease. Diabet Med. 2001; 18(10): 842-5. doi: 10.1046/j.14645491.2001.00585.x.

15. Habuchi T., Suzuki T., Sasaki R. et al. Association of vitamin D receptor gene polymorphism with prostate cancer and benign prostatic hyperplasia in a Japanese population. Cancer Research. 2000; 60(2): 305-8.

16. Sinotte M., Rousseau F., Ayotte P. et al.Vitamin D receptor polymorphisms (Fokl, Bsml) and breast cancer risk: association replication in two casecontrol studies within French Canadian population. Endocrine-Related Cancer. 2008. 15(4): 975-83. doi: 10.1677/ERC-08-0056.

17. Kim J.S., Kim Y.I., Song C. et al. Association of Vitamin D Receptor Gene Polymorphism and Parkinson's Disease in Koreans. J Korean Med Sci. 2005; 20(3): 495-8. doi:10.3346/jkms.2005.20.3.495.

18. Montazeri-Najafabady N., Dabbaghmanesh M.H., Mohammadian A.R. et al. Association of Vitamin D Receptor Bsml Gene Polymorphism with BMD Z-Score in Iranian Children and Adolescents (9-18 Years 0ld). Int J Endocrinol Metab, 2019; 17(2): e82677. Published online 2019 Apr 23. doi: $10.5812 /$ ijem. 82677.

19. Wei S., Tanaka H., Seino Y. Local action of exogenous growth hormone and insulin-like growth factor-I on dihydroxyvitamin $D$ production in LLC-PK1 cells. Eur J Endocrinol. 1998; 139(4): 454-60. doi: 10.1530/ eje.0.1390454.

20. Henry H.L. Regulation of vitamin D metabolism. Best Pract Res Clin Endocrinol Metab. 2011; 25(4): 531-41. doi: 10.1016/j. beem.2011.05.003.

21. Marcus R., Butterfield G., Holloway L. et al. Effects of short term administration of recombinant human growth hormone to elderly people. J Clin Endocrinol Metab. 1990; 70(2): 519-27. doi:10.1210/ jcem-70-2-519.

22. Araya Z., Tang W., Wikvall K. Hormonal regulation of the human sterol 27-hydroxylase gene CYP27A1. Biochem J. 2003; 372(2): 529-34. doi: 10.1042/bj200 21651.

23. Pérez-Fernandez R., Alonso M., Segura C. et al. Vitamin D receptor gene expression in human pituitary gland. Life Sci. 1997; 60(1): 35-42.

24. Saggese G., Baroncelli G.I., Bertelloni S. et al. Effects of longterm treatment with growth hormone on bone and mineral metabolism in children with growth hormone deficiency. J Pediatr. 1993; 122(1): 37-45. doi: 10.1016/s0022-3476(05)83484-5.

25. Witkowska-Sedek E., Kucharska A., Ruminska M. et al. Relationship between 25(OH)D and IGF-I in children and adolescents with growth hormone deficiency. Adv Exp Med Biol. 2016; 912: 43-9. doi: 10.1007/5584_2016_212.

26. Savanelli M.C., Scarano E., Muscogiuri G. et al. Cardiovascular risk in adult hypopituitaric patients with growth hormone deficiency: is there a role for vitamin D? Endocrine. 2016; 52(1): 111-9. doi: 10.1007/s12020-0150779-3. 
27. Wei S., Tanaka H., Kubo T. et al. Growth hormone increases serum 1,25-dihydroxyvitamin D levels and decreases 24,25-dihydroxyvitamin D levels in children with growth hormone deficiency. Eur J Endocrinol Eur Fed Endocr Soc. 1997; 136(1): 45-51. doi: 10.1530/eje.0.1360045.

28. Condamine L., Menaa C., Vrtovsnik F. et al. Local action of phosphate depletion and insulin-like growth factor 1 on in vitro production of 1,25-dihydroxyvitamin D by cultured mammalian kidney cells. J Clin Invest. 1994; 94(4): 1673-9. doi: 10.1172/JCI117512.

29. Maylyan E.A. Vliyanie polimorfizma gena retseptora vitamina D 283 $A>G(B S M I)$ u zhenschin s osteoporozom v postmenopauze. [The influence of vitamin D receptor gene $283 \mathrm{~A}>\mathrm{G}$ (BSMI) polymorphism on osteoporosis in postmenopausal women]. Medicinskij vestnik Juga Rossii. 2016; 4: 32-38. (in Russian).

"Investigation of Vitamin D3 (VDR3) receptor Bsm1 gene polymorphism, VDR gene TaqI (rs731236) polymorphism, and VDR Gene ApaI polymorphism (rs7975232) and establishing an association of identified disorders with clinical manifestations of short stature and patient phenotype".

The authors declare that all the procedures and experiments of this study respect the ethical standards in the Helsinki Declaration of 1975, as revised in 2008(5), as well as the national law. Informed consent was obtained from all the patients included in the study.

\section{ORCID and contributionship:}

Elena V. Bolshova: 0000-0003-1999-6031 A, B,

Mariana A. Ryznychuk: 0000-0002-3632-2138 C,D

Dmitry A. Kvacheniuk: 0000-0001-6886-3804 ${ }^{\text {E, F }}$

\section{Conflict of interest:}

The Authors declare no conflict of interest.

\section{CORRESPONDING AUTHOR \\ Mariana A. Ryznychuk \\ Bukovinian State Medical University \\ 2 Teatralna Sq., 58000 Chernivtsi, Ukraine \\ tel: +380501920953 \\ e-mail: rysnichuk.mariana@gmail.com}

Received: 23.04 .2020

Accepted: 27.11 .2020

A - Work concept and design, B - Data collection and analysis, C - Responsibility for statistical analysis, D-Writing the article, $\mathbf{E}$-Critical review, $\mathbf{F}$ - Final approval of the article 